УДК 159.9:37:316.35

DOI https://doi.org/10.26661/2310-4368/2021-3-8

\title{
ОРГАНІЗАЦІЙНО-МЕТОДИЧНІ ЗАСАДИ ДОСЛІДЖЕННЯ ПСИХОЛОГІЧНОГО СУПРОВОДУ БАТЬКІВ, ЯКІ ВИХОВУЮТЬ ДІТЕЙ РАННЬОГО ВІКУ З ОСОБЛИВИМИ ОСВІТНІМИ ПОТРЕБАМИ
}

\author{
Реброва О. О. \\ аспірант \\ Інститут спеціальної педагогіки та психології імені Миколи Ярмаченка \\ Начіональної академії педагогічних наук України \\ вул. Максима Берлинського, 9, Київ, Украӥна \\ orcid.org/0000-0001-9540-7556 \\ alimp.kharkov@gmail.com
}

\begin{abstract}
Ключові слова: сиблінгова підсистема, психоедукація, психологічний супровід, діти з особливими освітніми потребами, родина, батьківсько-дитячі стосунки, модель.
\end{abstract}

У статті розглядається організація дослідження психологічного супроводу батьків, які виховують дітей раннього віку 3 особливими освітніми потребами. У процесі дослідження реалізована модель дослідження батьків, які виховують дітей з особливими освітніми потребами, на рівні двох підсистем, яка включає чотири напрями: індивідуальний, шлюбний, батьківський, батьківсько-дитячий.

Проаналізовано, що шлюбна підсистема характеризує інтимні взаємини між подружжям і передбачає прояв симпатії та почуттів, те, як потрібно ставитися до свого партнера в стресовій ситуації, як вирішувати конфліктні ситуації. Визначено, що важливою умовою успішної діагностики $\epsilon$ встановлення партнерських стосунків психолога 3 подружжям. Батьківська підсистема тісно взаємопов'язана з основними завданнями щодо догляду за дітьми й виховним процесом. Особливості взаємодії в родині впливають на різні аспекти розвитку дитини. Від батьківського ставлення до дитини формується відчуття власної адекватності. У процесі цього дитина розуміє, яка модель поведінки є прийнятною.

Процес психодіагностики родини організовано й реалізовано за такою схемою: на підготовчому етапі здійснюється підбір методів і психологічних методик для вивчення батьків та організація й підготовка до психодіагностичних процедур; на другому етапі, який ми йменуємо як дослідницький, відбувається системна реалізація методів дослідження; на третьому - здійснюється аналіз отриманих результатів; на останньому етапі - інтерпретаційному - здійснюється обговорення отриманих результатів, надається обгрунтоване визначення психологічного сімейного стану, чітке розуміння типів сімейних проблем членами родини, а також зміни сімейних взаємин.

Визначено, що ефективним результатом проведення дослідження батьків, які виховують дитину з проблемами розвитку, стане реалізація таких завдань: проведення аналізу цілей, які ставлять перед собою батьки, i основних прагнень батьків; отримання ними інформації, що вплине на розуміння власних проблем; чітке усвідомлення й розуміння позитивних змін під час батьківсько-дитячої взаємодії; концентрація на внутрішні ресурси з метою отримання очікуваного результату в їхньому житті.

Запропоновано використання комплексу емпіричних методів. Визначено, що вихідним емпіричним фактажем для визначення особливостей батьківсько-дитячих стосунків стали змінні, які визначені через реалізацію стандартизованих психодіагностичних засобів. 


\title{
ORGANIZATION OF RESEARCH OF PSYCHOLOGICAL SUPPORT OF PARENTS RAISING EARLY CHILDREN WITH SPECIAL EDUCATIONAL NEEDS
}

\author{
Rebrova O. O. \\ Postgraduate Student \\ National Academy of Educational Sciences Mykola Yarmachenko \\ Institute of Special Education And Psychology \\ Maksyma Berlynskoho str., 9, Kiev, Ukraine, \\ orcid.org/0000-0001-9540-7556 \\ alimp.kharkov@gmail.com
}

Key words: sibling subsystem, psychoeducation, psychological support, children with special educational needs, family, parent-child relationships, model.
The article considers the organization of a study of psychological support for parents raising young children with special educational needs. In the process of research, a model of research of parents raising children with special educational needs at the level of two subsystems was implemented, which includes four areas: individual, marriage, parent, child-parent.

We have implemented a model of research of parents who raise children with special educational needs at the level of two subsystems and which includes four areas: individual, marriage, parent, child-parent.

It was analyzed that the marriage subsystem characterizes the intimate relationship between spouses and involves the expression of sympathy and feelings, how to treat your partner in a stressful situation, how to resolve conflict situations. It is determined that an important condition for successful diagnosis is the establishment of a partnership between the psychologist and the spouse. And the parent subsystem is closely interconnected with the main tasks of child care and the educational process. Features of interaction in the family affect various aspects of child development. From the parental attitude to the child the feeling of own adequacy is formed. In the process, the child understands which pattern of behavior is acceptable.

The process of family psychodiagnostics was organized and implemented according to the following scheme: at the preparatory stage the selection of methods and psychological methods for the study of parents and the organization and preparation for psychodiagnostic procedures; in the second stage, which we call research: there is a systematic implementation of research methods; on the third - the analysis of the received results is carried out; at the last stage - interpretive: the results are discussed, a reasonable definition of the psychological marital status, a clear understanding of the types of family problems by family members, as well as a change in family relationships. It is determined that an effective result of the study of parents raising a child with developmental problems will be the implementation of the following tasks: analysis of the goals set by parents and the main aspirations of parents; receiving information that will affect the understanding of their own problems; clear awareness and understanding of positive changes during child-parent interaction; focusing on internal resources in order to obtain the expected result in their lives.

The use of a set of empirical methods is proposed. It is determined that the initial empirical fact for determining the features of the child-parent relationship were variables, which were determined through the implementation of standardized psychodiagnostic tools. 
Постановка проблеми. Сучасна психологічна наука характеризує родину як систему, у якій кожний із ії членів знаходиться в численних і різноманітних взаємозв'язках з іншими структурними одиницями. Тому діагностична форма психологічного супроводу батьків має включати всіх ii членів, які не обов'язково присутні під час діагностичної процедури, а вивчаються через призму суб' єктивного бачення тих, хто безпосередньо бере участь в експерименті.

Психологічний супровід батьків, що виховують дитину з особливими освітніми потребами, $\epsilon$ новою сферою діяльності практичного психолога, у наш час не вистачає наукових праць, які б узагальнили знання та практичний досвід, у сфері проведення роботи з батьками.

Таким чином, наукове дослідження має на меті збільшити знання в психодіагностиці, психоедукації, психоконсультуванні та психотерапії родин, що виховують дітей 3 особливими освітніми потребами. Ці чотири складники є важливими етапами проведення психологічного супроводу.

Послідовна їх реалізації дає можливість охарактеризувати низку питань, що існують у практиці психологічного супроводу батьків, які виховують дитину 3 особливими освітніми потребами.

Аналіз останніх досліджень і публікацій. Проаналізувавши наукові праці відомих соціологів, психологів, педагогів, необхідно підкреслити, що проблему батьківсько-дитячих взаємин вивчала велика кількість відомих науковців, насамперед Е. Берн, Д. Боулбі, Е. Еріксон, В. Сатір, К. Роджерс 3. Фрейд, Е. Фромм, К. Хорні та ін. Учені Ю. Альошина, А. Бандура, Л. Божович, В. Дружинін, 3. Кісарчук, Л. Орбан-Лембрик акцентували увагу на важливості впливу батьківського ставлення на розвиток особистості.

Наприклад, О. Колишкін досліджує основні завдання роботи з родинами, що виховують дітей 3 особливими освітніми потребами, які, на нашу думку, відповідають і завданням психологічної роботи [7]: реконструкцію батьківсько-дитячих взаємин; удосконалення шлюбних і внутрішньородинних взаємин; гармонізацію міжособистісних взаємин між матір'ю, дитиною, іншими представниками родини; розвиток комунікативних форм поведінки, що сприяють самоактуалізації й самоствердженню дорослих, які виховують дитину з вадами розвитку; формування відповідних навичок соціальної взаємодії; особистісне зростання членів родини дитини 3 особливими освітніми потребами.

Учені О. Галяні 3. Борисенко в дослідженнях указують на важливість психологічної діагностики батьків дітей $з$ особливими освітніми потребами [4].
Вивчення батьківсько-дитячих відносин і труднощів досліджено в наукових працях українських учених, а саме: О. Абрамової, Т. Вісковатової, Н. Погорільської, М. Радченко, Т. Рябовол. У більшості досліджень основним предметом вивчення були батьки 3 дітьми, які мають психофізичні та інтелектуальні розлади.

Проаналізувавши наукові розробки вчених, можемо констатувати, що сьогодні не досліджено моделювання психологічного супроводу батьків, які виховують дітей раннього віку з особливими освітніми потребами.

Мета статті - обгрунтування організаційнометодичних засад дослідження психологічного супроводу батьків, які виховують дітей раннього віку з особливими освітніми потребами.

Основний виклад матеріалу дослідження. Основна одиниця аналізу - це ядерна родина та особливості їі існування на рівні двох підсистем - шлюбної та батьківської. Сиблінгова підсистема досліджується через призму бачення подружжя й батьків.

Розглянуті теоретико-методологічні положення сімейної психології стали фундаментом для більш глибокого розуміння функціонування родини, що базується на структурі, динаміці та наявній історії сімейної системи. Подальша системна процедура психологічного супроводу потребує детального обгрунтування моделі процесу діагностики й підбору діагностичного інструментарію для членів родини.

Концептуалізація проблеми функціонування родини за допомогою виділення важливих одиниць аналізу є основним теоретико-методологічним завданням. Саме діагностичну стратегію охарактеризуємо як формалізоване, чітке уявлення про цілі діяльності, етапи й засоби забезпечення результату, а також необхідні для цього ресурси емпіричного дослідження: спостереження, бесіда, анкетування, тестування.

Нами реалізована модель дослідження батьків, які виховують дітей 3 особливими освітніми потребами, на рівні двох підсистем, яка включає чотири напрями: індивідуальний, шлюбний, батьківський, батьківсько-дитячий.

Шлюбна підсистема характеризує інтимні взаємини між подружжям і передбачає прояв симпатії та почуттів, те, як потрібно ставитися до свого партнера в стресовій ситуації, як вирішувати конфліктні ситуації. Ця підсистема $є$ найскладнішою для дослідження, вона багато в чому прихована від очей сторонніх. Важливою умовою успішної діагностики $€$ встановлення партнерських стосунків психолога $з$ подружжям. Результативним засобом у цьому випадку є спостереження.

Батьківська підсистема тісно взаємопов'язана 3 основними завданнями щодо догляду за дітьми 
й виховним процесом. Особливості взаємодії в родині впливають на різні аспекти розвитку дитини. Від батьківського ставлення до дитини формується відчуття власної адекватності. У процесі цього дитина розуміє, яка модель поведінки $\epsilon$ прийнятною. За допомогою цієї підсистеми дитина набуває знання про властиві їі родині способи вирішення конфліктних ситуацій і належну модель поведінки в соціумі, які надалі застосовує у взаєминах з оточуючими людьми.

Розглянуті теоретико-методологічні положення сімейної психології стали фундаментом для більш глибокого розуміння функціонування родини, що базується на структурі, динаміці та наявній історії сімейної системи. Подальша системна процедура психологічного супроводу потребує детального обгрунтування моделі процесу діагностики й підбору діагностичного інструментарію для членів родини.

Концептуалізація проблеми функціонування родини за допомогою виділення важливих одиниць аналізу є основним теоретико-методологічним завданням. Саме діагностичну стратегію охарактеризуємо як формалізоване, чітке уявлення про цілі діяльності, етапи й засоби забезпечення результату, а також необхідні для цього ресурси емпіричного дослідження: спостереження, бесіда, анкетування, тестування.

Нами реалізована модель дослідження родинних напрямів, які виховують дітей $з$ особливими освітніми потребами, на рівні двох підсистем, яка включає чотири напрями: індивідуальний, шлюбний, батьківський, батьківсько-дитячий. Коротко охарактеризуємо їх.

Індивідуальний - це окремий представник родини. Аналізується існування окремого представника родини в контексті його великої кількості родинних взаємин.

Подружній являє собою основу ядерної родини, досліджує ii функціонування, включає подружню пару, взаємодія якої орієнтована на реалізацію особистих потреб подружжя на рівні «дорослий - дорослий».

Батьківський - включає всіх членів родини, що характеризуються як батьківська команда, а їхня співпраця спрямована на реалізацію батьківських завдань, до яких входить піклування про власних дітей, виховний процес, гармонійний розвиток особистості, адаптація. Характеризується специфікою взаємодій типу «батько - батько».

Батьківсько-дитяча - представлений батьками та їхніми дітьми, де специфіка функціонування дитини досліджується 3 позиції батьків, тобто правила поведінки в цьому напрямі окреслюються взаємодіями типу «батько - дитина», орієнтованими на виконання основних завдань формування у своїх дітей навичок управління психоемоційним станом, оволодіння дитиною загальноприйнятими нормами, соціальними цінностями і відповідними моделями взаємин у суспільстві. Саме в процесі цих взаємин дитина створює власну систему цінностей, набуває практичного досвіду щодо дотримання загальноприйнятих правил і законів, реалізуючи зобов'язання, моделюючи поведінку батьків.

Взаємини між усіма напрямами функціонування родини через фактори, механізми, параметри, які поєднані в ключові фокуси наукового дослідження, а саме: згуртованість, ієрархія, зовнішні й внутрішні рамки, гнучкість, рольова структура родини.

За допомогою діагностики наявних порушень щодо функціонування родини та викривлень їхніх уявлень відбувається детальне вивчення особливостей життєвих обставин батьків, зовнішніх й внутрішніх ознак, їхнього світобачення. Досліджується уявлення батьків про життя, їхнє «Я», ставлення до інших і світу в цілому, уявлення про себе як подружнього партнера, головні причини неблагополуччя в родині, уявлення про щоденні ситуації та обставини, що повторюються 3 невизначеною періодичністю. Це все окреслюють основні завдання та здійснення діагностичної процедури. Усвідомлення батьками психологічної проблеми, усвідомлення та правильне розуміння проблем, які в ній виникають, $€$ важливою передумовою вирішення проблем батьківсько-дитячих взаємин.

3 метою проведення дослідження індивідуально-психологічних характеристик батьків необхідно дослідити особистісні якості батьків, їхні ціннісні орієнтації, мотивацію, основні чинники, що здійснюють вплив на батьківські установки, рівень виховної й педагогічної компетентностей, виховних якостей, умінь і здібностей, особливостей особистісних переживань батьків щодо порушення розвитку дитини. Отримані дані сприяють вивченню такого: наскільки батьки, які мають дітей з особливими освітніми потребами, можуть володіти стресостійкими якостями, які необхідні для підтримки такої дитини й інших членів родини, можуть покращити умови життя.

Дослідження особливостей клімату в родині, взаємин між подружжям, місце суб'єкта в системі міжособистісних відношень і специфіка спілкування в родині - складне поняття, що окреслює процес передачі інформації; способи поведінки, взаємодію в сім'ї. Тому на цьому етапі нам необхідно дослідити сімейний клімат усередині родини та їхні взаємини; слабкі аспекти в процесі міжособистісної комунікації, реакції на стрес, які потребують психоконсультативного та психотерапевтичного втручання. 
У подальшому вивчається акцентуація на рівні диференціації - об'єднання сімейної системи зі зверненням до вже досліджуваних негативних психологічних наслідків «злиття», які описав М. Боуен [2, с. 24].

Вихідним пунктом дослідження $є$ спостереження за процесом обговорення наявних проблем у родинах. Визначення основних аспектів цього спектра проблем запобігає підвищенню та погіршенню ситуації в родині, визначає прогноз розвитку кожної конкретної родини.

Батьківсько-дитячі стосунки й аналіз взаємодії в родині: тип батьківського ставлення; стиль виховання та допущені помилки при цьому; моделі виховання, які реалізують батьки; специфіка сприйняття проблем власної дитини.

Аналізу структури родини дає можливість визначити, як виконуються іiї функції: який розподіл між членами родини прав та обов'язків, хто здійснює управління, хто підпорядкований виконавець тощо.

Життєвий цикл ядерної родини - це події, які відбуваються від іiї зародження, розвитку, становлення та функціонування, що є основним для проведення аналізу родинних взаємин, тому що дає можливість визначити їх контекст за допомогою опису нормативних завдань родини у визначений період іiі розвитку.

Важливого значення набуває уявлення про життєвий цикл родини в процесі вибору відповідної стратегії психологічної супровідної роботи 3 нею.

Саме регуляторами сімейної системи є насамперед iï функціонування, того, що сприяє дотриманню сімейних норм, правил, ритуалів, психологічно-культурних умов життя родини тощо.

Аналізуючи наукові положення Т. Ілляшенко й T. Жук [6], ми визначили, що близько половини батьків не мають мотивації прийняття порушень у розвитку дитини. Своєю чергою, потреба в прийнятті порушення пов'язана 3 потребою любити дитину незалежно від труднощів, які виникають у неї. Відсутність такої потреби призводить до явного чи прихованого відхилення дитини. Звідси витоки смислового бар'єру між батьками та психологами, який не дає змоги налагодити співпрацю на користь дитини.

Дослідження реалізується в суб'єкт-суб'єктній парадигмі. Людина разом із психологом чітко усвідомлює власну життєву ситуацію, ставлення до свого внутрішнього світу, до навколишньої дійсності в цілому.

Психолог у суб'єкт-суб'єктній парадигмі не досліджує людину, а допомагає їй відстежувати й чітко усвідомлювати стан її системи уявлень і взаємин із самою собою, іншими людьми, зовнішнім світом. Батьки стають активними учасниками цього процесу: психолог допомагає усвідомити особливості власної життєвої ситуації, краще пізнати внутрішній світ, починає розуміти внутрішні причини життєвих труднощів.

«Суб'єкт-суб'єктна» психодіагностика відбувається під час проведення бесіди, коли респондент розповідає про проблему, а психолог, використовуючи різні психотехніки, забезпечує належні умови для іiі проведення та направляє клієнта в потрібний напрям. У процесі діалогу член родини проявляє більшу активність. Під час проведення спільної роботи з вивчення проблеми 3 подальшою психоедукацією, психоконсультуванням і психотерапією в батьків з'являється нове бачення наявних труднощів.

Процес психологічного дослідження родини організовано й реалізовано за такою схемою:

- на підготовчому етапі здійснюється підбір психологічних методик для вивчення батьків;

- на другому етапі, який ми йменуємо як дослідницький, відбувається системна реалізація методів дослідження;

- на третьому етапі здійснюється аналіз отриманих результатів;

- на четвертому етапі - інтерпретаційному здійснюється обговорення отриманих результатів, надається обгрунтоване визначення психологічного сімейного стану, чітке розуміння типів сімейних проблем членами родини, а також зміни сімейних взаємин.

Таким чином, на основі проведеного аналізу нами визначено мету дослідження: 3'ясувати особливості й сформованість родинної системи на рівні двох підсистем.

Відповідно до наведеної мети дослідження, визначено завдання діагностичного процесу, a саме:

1. Вивчення типу батьківського ставлення.

2. Вивчення особливостей батьківсько-дитячих взаємин, стилів сімейного виховання та виділення їхніх психологічних причин.

3. Дослідження індивідуальних особливостей батьків, які виховують дітей з особливими освітніми потребами.

4. Забезпечення адаптації та регуляції поведінки батьків у стандартних i нестандартних ситуаціях.

5. Здійснення оцінки рівнів батьківсько-дитячих взаємин, визначення основних помилок, які допускають батьки в процесі виховання дітей 3 особливими освітніми потребами.

Уважаємо, що основним позитивним результатом проведення дослідження батьківсько-дитячих взаємин стане виконання таких завдань: проведення аналізу цілей, які ставлять перед собою батьки, й основних прагнень батьків; отримання ними інформації, яка вплине на розуміння влас- 
них проблем; чітке усвідомлення та розуміння позитивних змін під час батьківсько-дитячої взаємодії; концентрація на внутрішні ресурси 3 метою отримання очікуваного результату в їхньому житті.

Модель для дослідження родинної системи виконується під час усього психологічного супроводу, тому реалізується на інших його етапах, i представлена на рис. 1

Вивчення родинної системи в процесі психологічного супроводу відбувалося на базі Закарпатського обласного центру комплексної реабілітації «Дорого життя» в м. Ужгороді, Благодійного фонду «Інститут раннього втручання» в м. Харкові, KidsRehab, крорекційно-розвивального центру м. Києві та Центру АВА-терапії «Дім», м. Харків. Вибіркову сукупність становила 125 батьків, які перебували в цих центрах.

Усі респонденти зверталися за психологічною допомогою через такі причини:

- не знають, як правильно спілкуватися з дитиною, негативно ставляться до прояву незрозумілої поведінки дитини;

- відчувають негативні емоції та психосоматичні стани щодо поведінки дитини.

Кожна 3 досліджуваних родин мала одну дитину. Віковий діапазон усіх дітей був до 3-хроків.

Крім основних скарг, були й інші причини, які призводили до прояву неблагополуччя. Відповідно, обговорено проблеми, які з'являються в досліджуваних у повсякденному житті. Даючи відповіді на питання, батьки розповідали про те, які труднощі вони долають.

У процесі організації та проведення наукового дослідження ми пропонуємо використовувати комплекс емпіричних методів у їх взаємозв'язку. На основі прийнятого в психологічній науці підходу як методу психологічного аналізу пропонуємо реалізовувати методи вивчення соціальної ситуації, а саме: анкетування, бесіду з елементами активного й пасивного слухання, спостереження, психодіагностичні та проєктивні методики, кількісний і якісний методи статистичного опрацювання отриманих даних.

Таким чином, нами проведено анкетування, у якому були запропоновані запитання про вік, освіту, яким видом діяльності займаються батьки, оцінювання специфіки взаємин у родині, іiі склад.

3 метою узагальнення розуміння 3 приводу проявів психіки людини в природніх життєвих умовах проведено спостереження за такими параметрами: прагнення для налагодження адекватних контактів 3 іншими членами родини; форма й характер взаємин з іншими ії представниками; специфіка комунікації під час взаємодії з оточенням; особливості використання паралінгвістичних засобів спілкування; вибір переважаючої форми контакту, які важливі в повсякденному спілкуванні.

Крім того, уважаємо, що саме бесіда, під час якої тема визначається наявною сімейною ситуацією, є головним методом збору інформації про батьківсько-дитячі взаємини. У процесі бесіди відбувається налагодження контакту; визначається ставлення батьків до сімейної ситуації та зазначається його роль; вивчається рівень розвитку, інтересів, можливостей, особливостей характеру й темпераменту, поведінки, ставлення в родині; отримується значна кількість інформації про їхнє оточення. За допомогою запитань і спеціальних завдань у процесі бесіди відбувається психологічний вплив.

Відповідно до поставленої мети й завдань констатувального дослідження, нами розроблено діагностичний комплекс, комплекс вивчення родинної системи, який представлений у таблиці 1.

3 метою отримання об'єктивних результатів під час дослідження родинної системи детально подамо зміст методик, які ми включили в діагностичний комплекс і які відповідають досліджуваним параметрам, завданням, принципам,

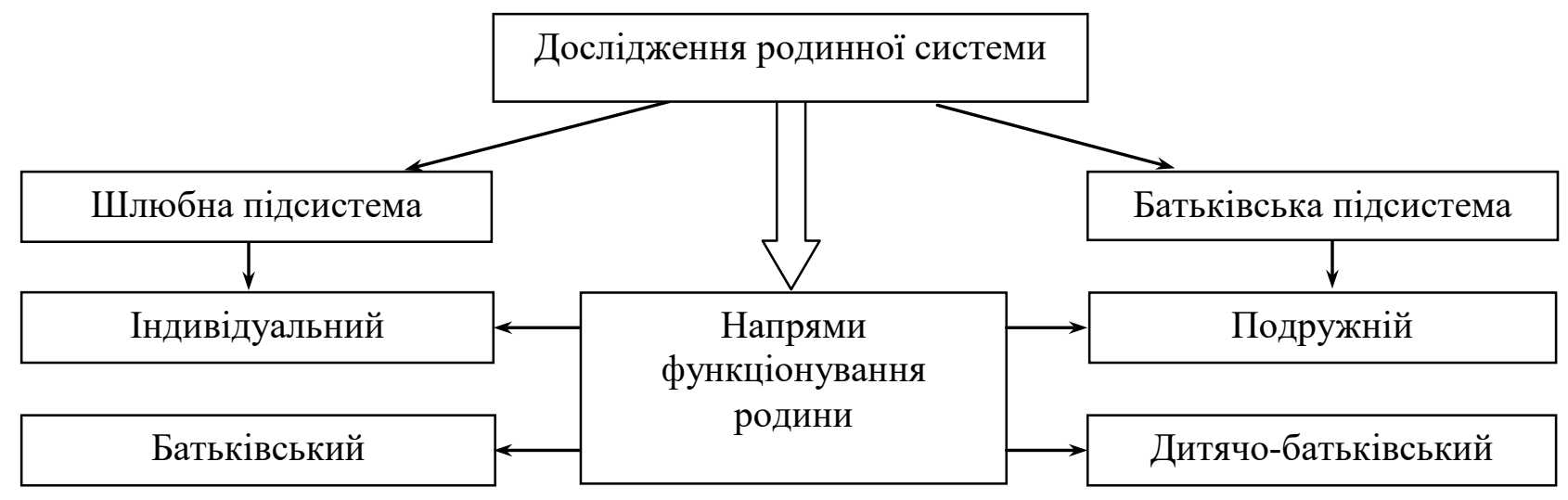

Рис. 1. Модель дослідження родинної системи 
Таблиця 1

Діагностичний комплекс дослідження родинної системи

\begin{tabular}{|c|c|c|}
\hline Компоненти & Показники & Діагностичний інструментарій \\
\hline $\begin{array}{l}\text { Шлюбна підси- } \\
\text { стема }\end{array}$ & $\begin{array}{l}\text { - емоційний стан членів подружжя та їхні особистісні ха- } \\
\text { рактеристики; } \\
\text { - стратегія поведінки в конфлікті; } \\
\text { - емоційна сфера подружніх взаємин, адаптація; } \\
\text { - виявлення особливостей міжособистісної взаємодії, } \\
\text { внутрішньосімейного спілкування та взаємодії, вияв- } \\
\text { лення тих їх аспектів, що призводять до непорозумінь і } \\
\text { конфліктів, з метою пошуку резервів адаптації подруж- } \\
\text { жя один до одного }\end{array}$ & $\begin{array}{c}\text { «Аналіз сімейних взаємин» (АСВ) } \\
\text { Е. Ейдеміллера } \\
\text { та В. Юстицкіса } \\
\text { «Фрайбурзький особистісний опи- } \\
\text { тувальник» (Freiburg Personality } \\
\text { Inventory, FPI) }\end{array}$ \\
\hline $\begin{array}{l}\text { Батьківська під- } \\
\text { система }\end{array}$ & $\begin{array}{l}\text { - стиль батьківського ставлення як комплексу різних по- } \\
\text { чуттів до дитини, поведінкових стереотипів, специфіки } \\
\text { комунікації нею, сприйняття й розуміння характеру осо- } \\
\text { бистості дитини, її вчинків; } \\
\text { - активна участь батьків у процесі виховання своєї дитини; } \\
\text { - адекватність поведінки батьків у знайомій /незнайомій } \\
\text { ситуації; } \\
\text { - забезпечення зворотного зв’язку; } \\
\text { • вибір адекватних способів спілкування; } \\
\text { - вибір етично-ціннісних зразків поведінки; } \\
\text { - прагнення до взаємодії }\end{array}$ & $\begin{array}{l}\text { Вивчення акцентуацій характеру } \\
\text { (А. Егідес у модифікації } \\
\text { І. Слободянюка, О. Холодової, } \\
\text { О. Олексенко } \\
\text { Вивчення батьківського } \\
\text { ставлення } \\
\text { (А. Варга, В. Столін) }\end{array}$ \\
\hline
\end{tabular}

функціям діагностики, а також основним принципам валідності й надійності.

Висновки та перспективи подальших досліджень. На основі проведеного дослідження визначено, що вихідним емпіричним фактажем для визначення характеристик батьківсько-дитячих стосунків і психологічного мікроклімату в родині з «особливими дітьми» стали змінні, які визначені за допомогою стандартизованих психодіагностичних засобів.

Перспективою подальших досліджень $є$ побудова програми психологічного супроводу батьків дітей раннього віку з особливими освітніми потребами: застосування психотренінгових технологій з метою оптимізації дитячо-батьківських стосунків та емоційного мікроклімату в родині.

\section{ЛІТЕРАТУРА}

1. Бодалев А.А., Столин В.В. Общая психодиагностика. Санкт-Петербург : Речь, 2006. 440 с.

2. Боуэн М. Духовность и личностно-центрированный подход. Вопросы психологии. 1992. № 3-4. С. 24-33.

3. Варга А.Я. Системная психотерапия супружеских пар. Москва : Когито-Центр, 2016. 342 с.

4. Галян О.І., Борисенко 3.T. Психологічні аспекти супроводу батьків дітей з особливими освітніми потребами. Теорія і практика сучасної психології: зб. наук. пращь. 2019. № 2, т. 2. С. 44-49.

5. Егидес А. Как разбираться в людях, или Психологический рисунок личности. Москва : АСТ-Пресс, $2002.94 \mathrm{c}$.

6. Ілляшенко Т.Д., Жук Т.В. Проблема психолого-педагогічної допомоги батькам, які виховують дітей з особливими освітніми потребами. Харківський осінній марафон психотехнологій 2019 : тези доповідей. Частина 2. URL: http://lib.iitta.gov.ua/717936/1/Ілляшенко_Жук_2019_131-135.pdf (дата звернення: 27.09.2010).

7. Колишкін О.В. Особливості корекційної педагогічної роботи із сім'ями, що виховують дітей 3 особливими освітніми потребами. Соціальна підтримка сім'ї та дитини у соиіокультурному просторі громади : матеріали Всеукраїнської науково-практичної конференції з міжнародною участю (11-12 листопада 2015 р.). Суми : СумДПУ імені А.С. Макаренка, 2015. С. 38-41.

8. Кукуруза Г.В. Аналіз дитячо-батьківських відносин як складова міждисциплінарної оцінки розвитку дітей в системі раннього втручання. Соціальна педіатрія : збірник наукових праць. Київ : Інтермед, 2005. Вип. III. С. 289-291.

9. Луценко О.Л. Фрайбурзький особистісний опитувальник FPI - перевірка валідності та локальна стандартизація. Вісник Харківського національного університету імені В.Н. Каразіна. Серія «Психологія». 2016. Вип. 61. С. 49-54.

10. Миронова С.П. Работа с родителями как один из путей реализации коррекционного компонента инклюзивного обучения. Комплексное сопровождение детей с ограниченными возможностями 
здоровья: развитие инновационных моделей : сборник научных статей / Чуваш. гос. пед. ун-т ; отв. ред. Т.Н. Семенова. Чебоксары : Чуваш. гос. пед. ун-т, 2015. С. 3-5.

11. Эйдемиллер Э.Г., Юстицкис В.Ю. Психология и психотерапия семьи. Санкт-Петербург : Питер, $1999.656 \mathrm{c}$.

12. Twardowski A. Sytuacja rodzin dzieci niepełnosprawnych. Dziecko niepetnosprawne $w$ rodzinie. Warszawa : WSiP., 1991. S. 18-54.

13. Blasher J., Sequential stages of parental adjustment to the birth of a child with handicaps : fact or artifact? Mental retardation. 1984. Vol. 22. P. 55-68.

\section{REFERENCES}

1. Bodalev A. A., Stolin V. V. (2006) Obshhaja psihodiagnostika. [General psychodiagnostics]. St. Petersburg : Speech [in Russian].

2. Boujen M. (1992) Duhovnost' i lichnostno-centrirovannyj podhod. [Spirituality and a person-centered approach]. Moscow : Questions of Psychology [in Russian].

3. Varga A. Ja. (2016) Sistemnaja psihoterapija supruzheskih par.[Systemic psychotherapy for married couples]. Moscow : Cogito-Center [in Russian].

4. Galyan O.I., Bory`senko Z.T. (2019) Psy`xologichni aspekty`suprovodu bat'kiv ditej z osobly 'vy ‘my osvitnimy 'potrebamy'. [Psychological aspects of accompanying parents of children with special educational needs]: zb. Science. wash. № 2, t. 2. K., S. 44-49 [in Ukrainian].

5. Egides A. (2002) Kak razbirat'sja v ljudjah, ili Psihologicheskij risunok lichnosti. [How to understand people, or the Psychological drawing of a person]. Moscow : AST-Press [in Russian].

6. Illyashenko T.D., Zhuk T.V. (2019) Problema psy`xologo-pedagogichnoyi dopomogy` bat'kam, yaki vy`xovuyut ditej z osobly`vy`my` osvitnimy` potrebamy`. [The problem of psychological and pedagogical assistance to parents raising children with special educational needs]. Kharkiv Autumn Marathon of Psychotechnologies 2019: abstracts. Part 2. http://lib.iitta.gov.ua/717936/1/Ілляшенко_Жук_2019_131-135. pdf (дата звернення: 27.09.2010).

7. Lucenko O. L. (2016) Frajburz 'ky`j osoby `stisny`j opy`tuval ny`k FPI - perevirka validnosti ta lokal'na standarty zaciya [Freiburzskiy special opituvlik FPI - revision of validity and local standardization.] Visnik of Kharkiv National University for the Name of V. N. Karazin. Series: Psychology [in Ukrainian].

8. Koly'shkin O.V. (2015) Osobly'vosti korekcijnoyi pedagogichnoyi roboty' iz sim'yamy', shho vy'xovuyut' ditej z osobly 'vy`my` osvitnimy' potrebamy` [Features of correctional pedagogical work with families raising children with special educational needs ]. Social support of the family and children in the socio-cultural space of the community: materials of the All-Ukrainian scientific-practical conference with international participation, (November 11-12, 2015). Sumy: Sumy State Pedagogical University named after AS Makarenko, P. 38-41 [in Ukrainian].

9. Kukuruza H. V. (2005) Analiz dytiacho-batkivskykh vidnosyn yak skladova mizhdystsyplinarnoi otsinky rozvytku ditei v systemi rannoho vtruchannia [Analysis of child-parent relations as a component of interdisciplinary assessment of children's development in the system of early intervention ] Social Pediatrics: Coll. Science. works.-K., Intermed [in Ukrainian].

10. Mironova S.P. (2015) Rabota s roditelyami kak odin iz putej realizacii korrekcionnogo komponenta inklyuzivnogo obucheniya [Working with parents as one of the ways to implement the correctional component of inclusive education]. Comprehensive support of children with disabilities: the development of innovative models: collection of scientific articles / Chuvash. state ped. un-t; otv. ed. T.N. Semenova. Cheboksary : Chuvash. state ped. un-t. S. 3-5 [in Russian].

11. Jejdemiller Je. G., Justickis., V. Ju. (1999) Psihologija i psihoterapija sem'i. [Family psychology and psychotherapy]. Saint Petersburg : Peter [in Russian].

12. Twardowski A. Sytuacja rodzin dzieci niepełnosprawnych / A. Twardowski; [red. I. Obuchowska] // Dziecko niepełnosprawne w rodzinie. - Warszawa : WSiP., 1991. - S. 18-54.

13. Blasher J., Sequential stages of parental adjustment to the birth of a child with handicaps : fact or artifact? Mental retardation. 1984. Vol. 22. P. 55-68. 